\title{
BRAIN FUNCTION
}

CORTICAL EXCITABILITY AND STEADY POTENTIALS RELATIONS OF BASIC RESEARCH TO SPACE BIOLOGY 




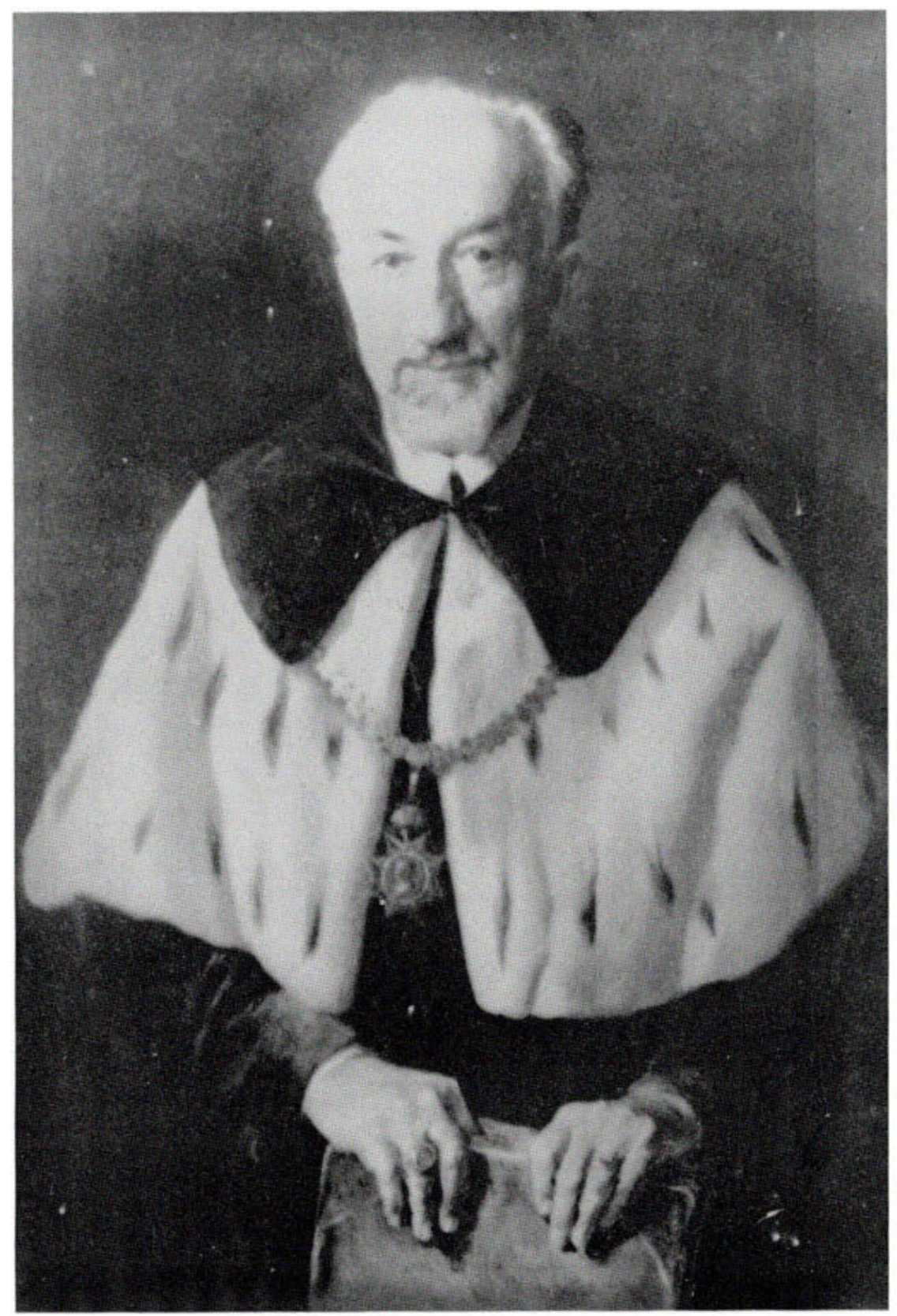

\section{A D O L F B E C K \\ $1863-1942$}

In rectorial robes, wearing the ring given him in honor of forty years of service to the University of Jan Kasimir in Lvov (Poland), and holding the book he wrote with Cybulski on The Physiology of Man. 


\section{UCLA FORUM IN MEDICAL SCIENCES}

NUMBER 1

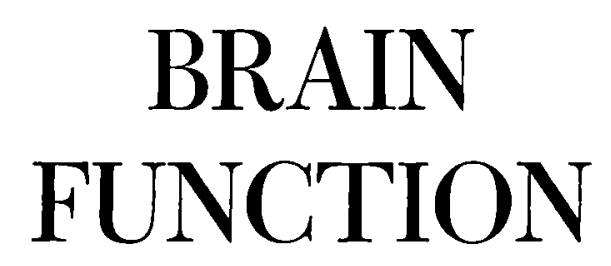

Proceedings of the First Conference, 1961

CORTICAL EXGITABILITY AND STEADY POTENTIALS RELATIONS OF BASIC RESEARCH TO SPACE BIOLOGY

Sponsored by the Brain Research Institute, University of California, Los Angeles, in collaboration with the American Institute of Biological Sciences and with the support of the U.S. Air Force Systems Command

EDITOR

MARY A. B. BRAZIER

UNIVERSITY OF CALIFORNIA PRESS

BERKELEY AND LOS ANGELES 


\section{CITATION FORM}

Brazier, M. A. B. (Ed.), Brain Function, Vol. I: Cortical Excitability and Steady Potentials; Relations of Basic Research to Space Biology. UCLA Forum Med. Sci. No. 1, Univ, of Calif. Press, Los Angeles, 1963.

University of California Press Berkeley and Los Angeles, California

Cambridge University Press London, England

Library of Congress Catalog Card Number: 64-22268

Printed in the United States of America 


\title{
PARTICIPANTS IN THE CONFERENCE
}

\author{
H. W. Magoun, Co-Chairman \\ Brain Research Institute, University of California Medical Center \\ Los Angeles 24, California \\ F. Fremont-Smith, Co-Chairman \\ American Institute of Biological Sciences \\ Time and Life Building, Rockefeller Center \\ New York 20, New York \\ M. A. B. Brazier, Editor \\ Brain Research Institute, University of California Medical Center \\ Los Angeles 24, California
}

W. R. AdeY

Space Biology Laboratory, Brain Research Institute

University of California Medical Center

Los Angeles 24, California

J. A. V. Bates

The National Hospital, Queen Square

London, W. C. 1, England

J. M. BROOKHART

Department of Physiology, University of Oregon Medical School

Portland 1, Oregon

N. BUCHWALD

Brain Research Institute, University of California Medical Center

Los Angeles 24, California

T. H. BULLOCK

Department of Zoology, University of California

Los Angeles 24, California

H. CASPERS

Physiologisches Institut der Universität Münster

Münster (Westf.), Germany 
M. R. DE Lucch"

U. S. Air Force, Space Systems Division

Inglewood, California

E. DE ROBERTIS

Instituto de Anatomía General y Embriología, Universidad Nacional

Buenos Aires, Argentina

E. Emelberg

Barrow Neurological Institute

Phoenix, Arizona

J. D. French

Brain Research Institute, University of California Medical Center

Los Angeles 24, California

S. Goldring

Division of Neurosurgery, Washington University School of Medicine

St. Louis 10, Missouri

B. Grafstein $†$

Department of Physiology, McGill University

Montreal 2, Canada

R. J. GuMnit

Department of Neurology, State University of Iowa Hospitals

Iowa City, Iowa

W. Haymaker

National Aeronautics and Space Administration, Ames Research Center Moffett Field, California

J. P. Henry

Department of Physiology, University of Southern California School of Medicine Los Angeles 7, California

A. A. P. LEÃo

Instituto de Biofísica, Universidade do Brasil

Rio de Janeiro, Brasil

R. B. Livingston

Laboratory of Neurobiology, National Institutes of Health

Bethesda 14, Maryland

* Currently assigned to the Brain Research Institute, University of California, Los Angeles.

† PRESENT ADDRESS: Rockefeller Institute

New York 21, N.Y. 


\section{S. LUSE}

Department of Anatomy, Washington University School of Medicine

St. Louis 10, Missouri

H. McIllwain

The Maudsley Hospital, Denmark Hill

London, S.E. 5, England

F. MORRELL

Division of Neurology, Stanford Medical Center

Palo Alto, California

D. P. Purpura

Department of Neurological Surgery

Columbia University College of Physicians and Surgeons

New York 32, New York

O. E. Reynolds

National Aeronautics and Space Administration

Federal Office Building 6

Washington 25, D.C.

V. Rowland

Department of Psychiatry, School of Medicine

Western Reserve University

Cleveland, Ohio

V. S. Rusinov*

Institute of Higher Nervous Activity, Academy of Sciences of the USSR

Moscow, USSR

A. Van Harreveld

Department of Biology, California Institute of Technology

Pasadena, California

A. A. WARD, JR.

Department of Neurosurgery, School of Medicine

University of Washington

Seattle, Washington

* Not present. 


\title{
UCLA FORUM IN MEDICAL SCIENCES
}

\author{
EDITORLAL STAFF \\ Victor E. Hall, Editor \\ Martha Bascopé-Vargas, Assistant Editor
}

EDITOHIAL BOARD

Forrest H. Adams William P. Longmire

Mary A. B. Brazier H. W. Magoun

Louise L. Darling Sidney Roberts

Morton I. Grossman Emil L. Smith

John S. Lawrence Reidar F. Sognnaes

U NIVERSITY OF CALIFORNIA, LOS A NGEES 


\section{UCLA FORUM IN MEDICAL SCIENCES}

\section{A Preface to the Series}

When recently in Los Angeles as a Visiting Professor, Dr. Jan Waldenström observed the irony of one of the pendular swings in the history of science. In medieval times, he pointed out, scientific publications were so few that interested scholars could learn of foreign accomplishments chiefly through personal visits. Now the vast number of burgeoning journals is sometimes a formidable barrier between the inquirer and the exposed heart of a large problem-thus does ultra-modernity lead to medieval methods of learning!

Whether for medieval or modern reasons, the visits of those who bring a point of view, a provocative question and, above all, an answer, are invigorating and welcome occasions. Sometimes convergent visits, planned as symposia, seem to organize, if only temporarily, and therefore challengingly, a shifting assortment of facts and ideas otherwise difficult to hold in focus.

The editing and publication of such meetings which are periodically held at UCLA seemed to us to be one small part of an answer to a large need accentuated by the "information explosion". This need was described by President Kennedy's Science Advisory Committee in a report entitled "Science, Government, and Information" and editorially pin-pointed in Science as follows: "One recommendation which could be implemented is that some scientists and engineers 'commit themselves deeply to the job of sifting, reviewing, and synthesizing information' since 'reviewing, writing books, criticizing, and synthesizing are as much a part of science as is traditional research." "

Out of these considerations, and with this initial volume, the UCLA Forum in Medical Sciences has been created, to review, to synthesize and to analyze rather than to serve as another outlet for original papers. The Forum will be published irregularly as the spirit moves the Editorial Board and as those from our own school and from afar gather under its aegis for discussion.

The topics will vary widely from the deep roots of medicine in biology, chemistry and physics to the applied medical arts. It is our hope that each volume, whatever its subject, will in its sphere provide that broad view which stands between atomistic surfeit on the one hand and a formless void on the other.

Even more we hope that the Forum will reflect among participants, auditors and readers alike, a certain warmth felt by those whose labors are related by content and aspiration to works in distant lands and, indeed, related to life itself. 